\title{
El motivo literario del portante y otras claves interpretativas en «No oyes ladrar los perros» de Juan Rulfo ${ }^{1}$
}

\author{
Rosa Eugenia Montes Doncel \\ UNIVERSIDAD DE EXTREMADURA \\ rosamont@unex.es \\ Lucía Tena Morillo \\ UNIVERSIDAD DE EXTREMADURA \\ luciatenamorillo@gmail.com
}

Recibido: $2 / 1 / 2018$

Aceptado: 22/10/2018

\section{RESUMEN:}

El presente trabajo analiza en primer lugar el cuento de Juan Rulfo «No oyes ladrar los perros» desde una perspectiva pragmática y narratológica, explorando sus componentes de género. Siguiendo los procedimientos de la Literatura Comparada traza además un recorrido del motivo literario del portador desde los clásicos hasta el siglo XXI, aportando ejemplos de distintas literaturas. Combina los resultados de estos métodos con el estudio de los símbolos presentes en el relato para intentar llegar a la más correcta interpretación del texto.

PALABRAS CLAVE: Juan Rulfo, motivo del portador, componentes del cuento como género, tema de identidad, Literatura Comparada.

1 La realización de este trabajo ha sido posible gracias al Proyecto de Investigación FFI2017-82101-P, financiado por el Ministerio de Ciencia, Innovación y Universidades. La autoras pertenecen al Instituto de Investigación LingLap. 
The literary motive of the bearer and other interpretative keys in Juan Rulfo's «No oyes ladrar los perros».

\begin{abstract}
:
The present essay analyzes Juan Rulfo's tale titled «No oyes ladrar los perros» from a pragmatic and narratological point of view and explores its genre elements. On the basis of the methods applied by Comparative Literature, the essay traces the literary motive of 'the bearer' from the classics to the $21^{\text {st }}$ century using examples from different literary traditions. The results of these methods are combined with the study of the symbols in the text in order to reach its most proper interpretation.
\end{abstract}

KEY WORDS: Juan Rulfo, The Bearer motive, genre tale components, identity subject, Comparative Literature.

\title{
1. «No oyes ladrar los perros». Características genológicas y análisis pragmático-narratológico
}

«No oyes ladrar los perros», relato perteneciente a la breve, mítica y única colección publicada por Juan Rulfo, bajo el sonoro título de El Llano en llamas (1953), escapa, como lo hace en general el resto de los cuentos de su autor, a una adscripción ortodoxa a los constituyentes de este género narrativo que han sido inventariados por la crítica. En efecto, si tomamos como referencia estudios clásicos, por ejemplo el del formalista ruso Boris Eichenbaum, o, dentro de nuestras fronteras, los de Mariano Baquero Goyanes o Juan Paredes, son rasgos propios del cuento, determinados por sus dimensiones reducidas frente a las de la novela, la condensación (hace hincapié en esta propiedad Eichenbaum, 1991: 153), la economía o «casi carencia de diálogo» (Baquero Goyanes, 1988: 150), la parquedad de las descripciones y la carencia de excursos. El final, cifra hacia la cual se diseña todo el texto, ejecuta un acabado en punta, a menudo sorprendente, y ayuno de codas o añadidos anticlimáticos (Paredes, 2004: 8, 22 y ss.) $)^{2}$. Solidario con los

2 Genette llamaba «determinación retrógrada» a ese subordinar la narración a su final (Genette, 1969: 94). No podemos aquí detenernos en el deslinde entre los términos cierre (del texto), desenlace (de la historia) y otros afines como acabamiento o epílogo. Remitimos al excelente tratado de Marco Kunz, 1997. 
atributos mencionados figura también el del barroquismo dispositivo preconizado por eximios cultivadores del género como Poe o Chéjov. Se ha hecho célebre la aseveración del cuentista ruso, quien decía que si en la primera página de un relato el narrador describe minuciosamente una pistola, el relato debe concluir con la muerte del protagonista, causada por esa arma. Tal abigarramiento no tiene necesariamente por qué extenderse al plano elocutivo, como ocurre a menudo en la lírica, pero en lo que toca a la construcción basta tomar un cuento de Borges o Cortázar para probar la veracidad de esta norma: no cabe suprimir ni un párrafo, ni aun un par de líneas, sin correr el riesgo de perder el sentido. A diferencia de lo observable en novela, nada en el cuento, ni los motivos ni los personajes, puede ser anecdótico, ornamental o gratuito. El cuento comparte su intensidad formal y emocional con la lírica, aunque por su condición narrativa se le haya situado junto a la novela (Paredes, 2004: 29).

Si cuantitativamente el relato corto, según afirmaban H. G. Wells y Seymour Menton y glosa Baquero Goyanes (Baquero Goyanes, 1988: 123), es aquel que puede leerse en menos de una hora, «No oyes ladrar los perros» cumple esta premisa. Sin embargo, empieza por conculcar el establecimiento de esas tres partes estructurales diferenciadas, exposición, nudo y desenlace, que están por lo común bien definidas en el cuento, aunque sean susceptibles de diluirse en los géneros narrativos largos. El texto de Rulfo comienza in medias res, y, contraviniendo la regla que limitaba y casi proscribía el diálogo (Baquero Goyanes, 1988: 151), se configura básicamente sobre esa modalidad. De hecho, ilustra el tipo de cuento rulfiano bautizado por Carlos Blanco Aguinaga como 'cuento dramático dialogado', frente a las otras dos categorías tipificadas por este editor de El Llano en llamas: 'cuentos descriptivos sin acción', por ejemplo «Luvina», y 'cuentos que narran un acontecer externo', verbigracia «Talpa» (Rulfo, 1986a: 18-19). En «No oyes ladrar los perros» incluso la apertura presenta forma dialogada, y no se trata de un diálogo exclusivamente funcional, como pedían los tratadistas del cuento, sino 
que contribuye a dibujar la etopeya y circunstancias de sus dos interlocutores.

El incipit de nuestro cuento («-Tú que vas allá arriba, Ignacio, dime si no oyes alguna señal de algo o si ves luz en alguna parte./ - No se ve nada./ - Ya debemos estar cerca» [Rulfo, 2017: 225]) podría muy bien serlo de una novela. Pero cuando una novela empieza in medias res habitualmente el discurso nos procura más adelante los datos que nos faltan. El lector así lo entiende y aguarda la especificación de tales datos. De modo inverso, la convención pragmática respecto a la lírica sanciona que el poema opere como un 'fragmento de un conjunto superior' que se da por sabido y que no requiere ser actualizado en el texto.

«No oyes ladrar los perros» se abre pues muy a la manera de una novela en este diálogo descontextualizado: no sabemos quiénes hablan, ni en qué situación. En cambio, se comporta más como un poema que como una novela en el sentido de que no llega a precisar este contexto elidido, sino solo algunos de sus componentes. Tras siete intervenciones seguidas en estilo directo en las que no se entrevera acotación alguna, ni verbos dicendi que adjudiquen las palabras a los personajes que las emiten, el discurso en tercera persona que surge al fin no concreta la identidad ni el nombre de los hablantes, ni siquiera su número (aunque es fácil de colegir), sino tan solo su sexo: «La sombra larga y negra de los hombres...» (Rulfo, 2017: 225). Pero ¿de qué clase de sombra se trata? «Era una sola sombra, tambaleante» (Rulfo, 2017: 225), enuncia el texto antes del punto y aparte, mientras que el siguiente parágrafo, conformado por una única frase aislada, enuncia que la acción sucede al anochecer: «La luna venía saliendo de la tierra, como una llamarada redonda» [Rulfo, 2017: 225]. Otra vez se incorpora un pasaje dialogado, $\mathrm{y}$, seguidamente, la nueva aparición del narrador heterodiegético circunscribirá ya a este en el punto de vista de uno de los hablantes, el denominado 'el viejo', del que nunca sabremos el nombre; dicha focalización será la que se mantenga en todo el 
discurso, que podrá trasladarnos percepciones únicamente de este personaje, nunca del otro, llamado Ignacio según se nos ha notificado por vía mimética en la última de las oraciones pronunciadas por el primero antes de la emergencia del narrador («Pobre de ti, Ignacio» [Rulfo, 2017: 225]). Ignoramos, por ejemplo, si las gotas que caen sobre la cabeza del padre son lágrimas o sangre, si el hijo llora por el recuerdo de su madre o se ha desangrado hasta morir ${ }^{3}$.

3 Françoise Perus ha publicado en 2012 un análisis narratológico de «No oyes ladrar los perros» en un capítulo de su libro Juan Rulfo, el arte de narrar, del que no podemos sino disentir en buena medida. La autora parte, en este como en el resto de los comentarios del compendio, de un uso del sintagma 'narrador testigo' que contradice el establecido por los estudios clásicos de Narratología: «The witness-narrator is a character in the action, more or less acquainted with its chiefs personages, who speaks to the reader in the first person», escribió Norman Friedman hace más de medio siglo, y adujo como ejemplos el Marlow de Lord Jim y el Carraway de The Great Gatsby (Friedman, 1967: 125). Pero es posible consignar modelos muy representativos de este sistema también en las letras hispánicas: pensemos en San Manuel Bueno, mártir y Crónica de una muerte anunciada. Ambas nouvelles serían completamente distintas si sus respectivos narradores no fuesen tan limitados, y es en dicha limitación donde residen las grandes interrogantes de los dos discursos: el lector no sabrá nunca si Don Manuel murió incrédulo ni quién fue el primer amante de Ángela Vicario, porque ni la feligresa Ángela Carballino ni el cronista sin nombre de García Márquez conocen esos datos (el narrador de Crónica... ofrece una muestra de lo que Pozuelo Yvancos llamaría no propiamente narrativa autobiográfica, sino figuración del yo personal del autor; Pozuelo Yvancos, 2010: 21-22).

Tampoco parece Perus haber leído a Ilse Adriana Luraschi, que en su trabajo sobre Rulfo ya citaba profusamente a Friedman (Luraschi, 1976). Sí menciona a Genette (por ejemplo en 127), pero su libro no evidencia que maneje los términos y conceptos empleados por el teórico galo en Figures III (Genette, 1972) y sus posteriores trabajos; antes bien aparenta lo contrario. Cuando el narrador no es un personaje intradiegético, sino un ente impersonal abstraído de un discurso en tercera persona, ¿qué sentido tiene denominarle testigo? Y en cualquier caso, si esta especialista en Rulfo ha decidido aplicar un nuevo sentido a la expresión, ¿cómo no refuta o presenta antes la acepción extendida que se le ha dado tradicionalmente a tal expresión en las teorías anglosajona y francesa? Para Perus «[...] es menester dejar de confundir la presencia ocasional de un narrador segundo - al que acabamos de designar como narrador testigo - con la voz narrativa de la novela realista, pese al uso de la tercera persona gramatical que caracteriza a ambos» (Perus, 2012: 25. El subrayado es nuestro); tampoco demuestra la estudiosa dominar la clasificación y nomenclatura genettianas fundamentales que distinguen entre relator intra, extra, homo y heterodiegético, ni tiene claros los distintos tipos de focalización, ni el tér- 
El cuento que nos ocupa constituye, qué duda cabe, una obra abierta y ambigua, que deliberadamente deja sin colmar algunos de esos que el teórico de la Recepción Roman Ingarden llamaba 'huecos' (Lücken; Ingarden: 1989). Pero ello no obsta para que el autor haya sembrado pistas que conduzcan a sus lectores a despejar tales interrogantes en una u otra dirección. Entre esas elipsis, que una novela extensa a menudo resolvería, figura la causa de la postración de Ignacio. Se infiere que alguien le ha herido en una reyerta, pero Rulfo omite precisar el quién, el cuándo, el cómo o el por qué que conformarían la fábula aristotélica, siguiendo en esta actitud silente un modus operandi análogo al de otras relaciones ${ }^{4}$. Los lectores, además, no sentimos la necesidad de saber estas cosas, igual que ante una composición lírica no hay curiosidad por conocer el nombre del yo que enuncia el discurso si este no se expresa. Valga el caso del himno de José de Espronceda que comien-

mino narratario acuñado por Prince, ni menciona en absoluto las teorías de la ficción literaria cuando habla del realismo en la introducción del libro: estos errores y lagunas propedéuticos tornan inane y confuso todo su ejercicio de análisis. El título mismo del capítulo, ««No oyes ladrar los perros»: el oído y la mirada del narrador testigo", patentiza que Perus cataloga así al narrador heterodiegético y neutral de este cuento, al cual atribuye, no sabemos por qué, una «reminiscencia de una pasada vivencia» (127). Esta injustificada concepción de 'narrador testigo' se mantiene en el estudio introductorio de su edición de El Llano en llamas de 2017, pero nos hemos decidido sin embargo a citar por ella por ser la más reciente y porque aquí dicho error no anula los aciertos de otras aportaciones.

4 Por ejemplo, tras la lectura de «El hombre» concluimos que el perseguidor, un miembro de la familia Urquidi, persigue y mata al 'hombre', José Alcancía, porque este había asesinado a hachazos a varios familiares suyos, entre ellos a su mujer y a su hijo recién nacido, buscando matarle a él. Y a su vez José Alcancía quería matar a este Urquidi porque él había asesinado a su hermano. Pero, a diferencia de lo que ocurre con el asesinato de Don Lupe Terreros en «iDiles que no me maten!», el porqué y las circunstancias de esta primera muerte que desencadena el conflicto permanecen ignotos. También se resuelve mediante una elipsis temporal y un cambio de focalización la escena más climática de la historia, esto es, aquella en que el perseguidor mata al 'hombre'. Solo entonces surge el relato en primera persona del borreguero que ha encontrado el cadáver, y que es quien pronuncia el apellido del perseguidor. El narrador heterodiegético nunca había mencionado este nombre ni el del perseguido, que afloró en forma de vocativo en el discurso de su antagonista. 
za: «Para y óyeme ¡oh Sol! Yo te saludo» (Espronceda, 1990: 178). ¿Quién es ese yo? Pues ¿quién ha de ser?: el sujeto lírico, el vate, la representación del poeta ${ }^{5}$. En cambio, cuando leemos el incipit novelesco «Vine a Comala porque me dijeron que acá vivía mi padre, un tal Pedro Páramo» (Rulfo, 2007: 65), además de apercibirnos de que no nos las hallamos frente a una obra corriente, experimentamos el prurito de descubrir qué referencia se halla tras esa primera persona. Y, en efecto, la novela acabará desvelándonos la identidad y el nombre de su narrador principal, si no único: Juan Preciado, el hijo que el cacique de Comala tuvo con Dolores, la esposa a la que nunca amó. Bien es cierto que la revelación del nombre de este personaje narrador se retrasa en Pedro Páramo bastante más de lo que sería habitual en una novela homodiegética clásica, y que en esta dilación radica uno de los muchos y característicos índices de extrañamiento del texto.

En el relato corto, y en una nueva prueba de su posición intermedia entre el poema y la novela, elidir la designación del sujeto enunciativo no es tan común como hacerlo en las composiciones poéticas, donde no suele estar explícito, pero sí más frecuente y menos llamativo que en la novela. El propio Rulfo nos provee de varios cuentos en que el nombre del narrador homodiegético no ya se retrasa, sino que se omite por completo: así ocurre sin ir más lejos en los tres primeros de El Llano en llamas, «Nos han dado la tierra» (una curiosa enunciación que empieza usando el plural, en una suerte de sujeto colectivo), «La cuesta de las comadres»y «Es que somos muy pobres». A veces el discurso de este narrador innominado no es unívoco: convive con otros en el texto, como sucede con el del pastor de borregos en «El hombre», inserto en un discurso dominado por la tercera persona narrativa. Tampoco sabremos cómo se llama el relator de «Talpa», el cuñado de Natalia; ni el de «Luvina», de identidad más difusa que el anterior, que introduce el relato dialogado de otro enunciador sin nombre. «El día del derrumbe» articula una

5 Sobre las convenciones de la lírica como género cfr. en este aspecto Montes Doncel, 2008: 13 y ss. 
estructura similar a «Luvina»: aunque es un cuento dialogado, la mayor parte del texto corresponde a un interlocutor del que no se menciona el nombre (sí está presente el de su narratario, Melitón). Se deduce fácilmente que la primera persona gramatical responde al nombre de Macario en el cuento homónimo, pero este extremo no se halla expreso. Pocos datos tenemos del narrador de «Acuérdate», salvo que, al igual que el receptor intradiegético al que invoca ya desde el título, fue compañero de Urbano Gómez en la escuela.

Pero no es el escritor mexicano pionero en esta práctica; recordemos por ejemplo los narradores-protagonistas carentes de nombre de algunos cuentos de Poe («El cuervo» [«The Raven»], «La caída de la Casa Usher» [«The Fall of The House of Usher»], «El tonel del Amontillado» [«The Cask of Amontillado»]) o de Stephan Zweig («Carta de una desconocida» [«Brief einer Unbekannten»]).

La naturaleza y la causa de las graves lesiones de Ignacio, que le incapacitan para andar, derivan pues en una de esas elipsis que Ingarden reputaba no necesitadas de actualización o neutralización por parte del receptor ${ }^{6}$. Así mismo se silencia cualquier dato sobre la prehistoria de los personajes a excepción de los rememorados en voz alta por el padre: que Ignacio es un bandolero peligroso, que ha asesinado a más de una persona (entre ellas a su propio padrino), que la esposa del viejo y madre de Ignacio está ya muerta y que solo en su memoria el padre auxilia a un hijo al que ha maldecido ${ }^{7}$.

6 «[...] esos lugares de indeterminación de una obra literaria $[\ldots]$ no deben ser neutralizados en su concreción estética. [...] El lector sensible y con cierta cultura artística pasa en silencio sobre tales lugares de indeterminación, y justamente eso le permite constituir el objeto artístico pretendido por el artista, al menos con cierta aproximación. El lector menos cultivado [...] no presta atención a la prohibición de neutralizar tales lugares de indeterminación, y convierte obras de arte bien configuradas en un cotilleo barato e irritante [...]» (Ingarden, 1989: 48). La función del lector «[...] consiste en plegarse a las sugestiones y directivas que emanan de la obra, actualizando no cualquier aspecto arbitrario, sino los aspectos que la obra sugiere» (Ingarden, 1989: 41).

7 Repara Ángel Rama en que lo único que Ignacio pide a su padre es agua, y la respuesta del padre a esta petición («Aquí no hay agua. No hay más que piedras») 
La otra elipsis cardinal del texto es si Ignacio está vivo o muerto cuando la pareja llega a Tonaya, y esta duda se halla relacionada con la creencia de las ánimas en México ${ }^{8}$. El texto no ofrece una respuesta taxativa a tal cuestión, como no la ofrecía Pedro Páramo, la obra magna de su autor, a muchas de las que suscitaba, algunas también referentes a la estrecha línea con que la tradición mexicana pinta la frontera entre vida y muerte. Por ejemplo: ¿Están vivos o muertos Donis y su hermana? ¿Estuvo o no Susana San Juan casada con Florencio? ¿En qué momento muere Juan Preciado? ¿Violó Miguel Páramo a Ana, la sobrina del Padre Rentería? Rulfo contesta sin evasivas y negativamente a las dos primeras preguntas en la entrevista que le hizo José Carlos González Boixo: Donis y su hermana no existen, son alucinaciones de Juan Preciado, y Susana nunca llegó a desposarse con el idealizado Florencio, ni conoció nunca el mar. Pero aquí se diría que intentio operis e intentio auctoris (¿intención o declaración?) entran en conflicto porque, como señala González Boixo, la propia obra no confirma de modo categórico estas aserciones de su creador (Rulfo, 1986b: 38-39 y 184n; Rulfo, 2007: 30 y 31, 197-198, 201, 205 y 250). Era justamente una propiedad de la famosa novela rulfiana el estar compuesta por fragmentos climáticos que parecen ir saltando sobre lo accesorio: «[...] yo trato de evitar momentos muertos, en que no sucede nada. Doy el salto hasta el momento cuando al personaje le sucede algo» (Sommers, apud González Boixo

no es caprichosa, dado que el Nuevo Testamento utiliza precisamente la imagen de la piedra para representar la negativa despiadada de un padre a un hijo ( $« \mathrm{O}$ acaso hay alguno entre vosotros que al hijo que le pide pan le da una piedra [...]?» [Mateo, 7:9]). No se registra, por otro lado, ni una sola palabra de arrepentimiento por parte del hijo, que ha matado al padrino, al 'otro padre'; ni una sola palabra de piedad, amor o justificación por parte del padre. Cfr. Rama, 1975: 6-7.

8 Pensemos en el último filme de Pixar, Coco, que estos días triunfa en las salas mexicanas. Rulfo en Pedro Páramo emplea la figura de la prosopopeya en el sentido clásico y hoy bastante olvidado de este término: hacer hablar a los muertos (Fontanier, 1977: 404-406). 
[Rulfo, 1986b: 43]; González Boixo en Rulfo, 2007: 24, 38, 40-41 y 190; crf. Verdugo, 2006) ${ }^{9}$.

Esta condensación, que predispone a la elipsis y que exonera al relato de lo gratuito, esta sensación de que el texto es una parte desgajada de un mundo más amplio que se da por consabido, aproxima mucho a Pedro Páramo a la naturaleza de la lírica. Por otro lado, la índole funcional de los pasajes, que no aparecen deturpados por digresiones, descripciones fatigosas o episodios secundarios - por lo que coloquialmente se llama 'paja' de la novela-, unida a una moderada extensión y a la sencillez estilística, favorecen que Pedro Páramo sea una lectura mucho más atractiva que la mayoría de las novelas señeras del boom. Y ello a despecho de su atrevido experimentalismo y de que su complejidad estructural e interpretativa se adelanten a las de La muerte de Artemio Cruz (1962), Rayuela (1963) o Conversación en la Catedral (1969); la hoy cincuentenaria Cien años de soledad (1967), en cambio, escrita por cierto por un devoto confeso de Rulfo, aunque voluminosa sí resulta muy accesible para cualquier lector medio. Se produce así el caso de que la única novela de Rulfo tiende en su disposición hacia lo lírico y lo cuentístico, sin que pueda ponerse nunca en duda su estatus de novela, mientras que los cuentos de Rulfo, como vemos y seguiremos viendo, a más del tinte lírico propio del cuento se escoran en sus facturas al territorio de lo novelesco, pero sin adentrarse tampoco en franjas limítrofes. Por ejemplo, la escasez de descripciones usual en los cuentos suele estar dictada por la brevedad del género, sintético por ex-

9 Es muy significativo a este respecto el pasaje dialogado entre Pedro Páramo y El Tilcuate del fragmento 66. Como anota González Boixo (Rulfo, 2007: 171 y 205206), este corto diálogo reúne retazos de conversaciones más amplias, y se supone que muy semejantes entre ellas, habidas entre los dos personajes en distanciados momentos. El Tilcuate se hace primero seguidor de Carranza, luego de Obregón, y más tarde toma partido en la rebelión cristera. El fragmento 66 de Pedro Páramo constituye una variante, de original hechura, del fenómeno temporal que Genette llamó silepsis (Genette, 1972: 147), y que consiste en contar una vez en el discurso lo que sucedió $n$ veces en la historia. Hubo varios, y no un solo diálogo de esta laya, entre el cacique de Comala y el guerrillero. 
celencia y refractario a lo gratuito, mientras que en los relatos de El Llano en llamas es un factor que potencia el efecto de eclipse. Concretamente en «No oyes ladrar los perros» hay no ya escasez, sino notoria omisión de descripciones. Se mencionan pocos elementos espaciales, como la sombra conjunta de los personajes, el paredón, las piedras, el arroyo, la luna, y el tejaván y la acera del pueblo de Tonaya; aun estos pocos poseen una naturaleza funcional y no son descritos, excepto la luna, y ello porque los colores y situación del astro sirven para indicar el transcurrir de las horas, desde el ocaso hasta el amanecer ${ }^{10}$.

La negación del espacio, y, en contraste con ella, la especificación de los cambios cromáticos de la luna, cooperan a crear la atmósfera evanescente y feérica de este relato. No es un fenómeno dictado solo por imposiciones de la brevedad del género, y de hecho se registra en Pedro Páramo en la misma medida que en los cuentos, si bien en «No oyes ladrar los perros» esa ausencia se hace especialmente palmaria.

En las narraciones convencionales parece existir la necesidad de presentar el mundo en que los personajes se mueven. Veamos qué procedimientos elocutivos generan esa impresión, pero sin satisfacerla, en «No oyes ladrar los perros»: ya he señalado que en la primera intervención del narrador heterodiegético se denomina al conjunto formado por padre e hijo «la sombra larga y negra de los dos hombres». El determinante que introduce el sintagma es un artículo determinado, esto es, el emisor se refiere a esa sombra como si los lectores, a los que esta brusca apertura

$10 \mathrm{El}$ tiempo de la historia no es precisado por el narrador; tiene que extraerse de la mimesis. Respecto a este predominio de lo mimético (mostrado o dialogado) frente a lo diegético (contado), no es ocioso recordar el cariz cinematográfico de la prosa de Rulfo (vid. Paz Gago, 2000, y, sobre los mecanismos fílmicos de este cuento, la tesis de Cierlina, 2016: 269-277). El autor jalisciense fungió como guionista e incluso actuó de figurante, junto con otros conocidos intelectuales, en la película de Alberto Isaac En este pueblo no hay dragones (1965), basada en un relato de García Márquez. «No oyes ladrar los perros» es uno de los textos rulfianos que ha sido llevado cine: inspiró la cinta homónima del año 75 dirigida por François Reichenbach y coescrita por Carlos Fuentes. 
nos arroja sin preámbulos al camino de Tonaya ya de anochecida, conociésemos previamente a la tal sombra, o como si el sustantivo hubiese aparecido antes en el texto ${ }^{11}$.

En un poema lírico no preguntaríamos ¿qué sombra?, porque el mundo en la lírica no requiere ser presentado, pero en las narraciones sí. Otro tanto sucede, tras la siguiente sección dialogada, con 'el paredón' en el que el padre de Ignacio se ajusta su carga. ¿Qué paredón? Ni se nos ha hablado de ninguno hasta ahora ni se nos vuelve a hablar ya de este. Lo ortodoxo en la pragmática bien de relatos largos bien de breves sería: opción primera, utilizar el artículo indeterminado: «*El viejo [él en este punto sí ha aparecido previamente en el texto, por lo que está actualizado] se fue reculando hasta encontrarse con un paredón y se recargó allí, sin soltar la carga de sus hombros»; u opción segunda, explicar retroactivamente de qué paredón se trata. En cambio, este apartamiento de la convención narrativa en la solución de Rulfo deriva en uno de los factores de originalidad de sus narraciones, al tiempo que hace emanar de ellas su aura de piezas incompletas que se antojan separadas de un todo más amplio: diríase que preexiste un texto al que se le hubiesen tachado páginas, páginas que nosotros habremos de reconstruir; se provoca la sugerencia de que algo ha ocurrido en ese paredón. La lírica funciona del mismo modo en cuanto al uso del artículo indeterminado con sustantivos no contextualizados, pero como en lírica dicha práctica resulta inherente al género, no nos provoca extrañamiento.

En este mismo párrafo un breve salto hacia atrás informa de que «allá atrás, horas antes, le habían ayudado a echárselo a la espalda» [Rulfo, 2017: 226]. ¿Quién o quiénes? Nunca se nos dice. No ya la diégesis, sino la mimesis, el diálogo, nos permite deducir que el padre lleva a cuestas a este hijo que no puede andar,

11 Recuérdense en este punto las teorías del contexto de la pragmática lingüística y la teoría de lo consabido de Bello. Vid. Lázaro Carreter, 1980: 40-41, y Escandell, 1993: 35. Lázaro, como Coseriu, hablaba de contexto físico («cierra el armario»), empírico («¿Ha venido el lechero?»), práctico u ocasional («dame el rumbo»), histórico («Los Reyes Católicos»), o cultural («el manco de Lepanto»). 
y de una guisa tal que priva al cargador de oír: la oración de relativo en «Tú que llevas las orejas de fuera» [Rulfo, 2017: 225] implica que las del padre están tapadas, y este dato es confirmado por el discurso más adelante: ««Mira a ver si ya ves algo. $\mathrm{O}$ si oyes algo. Tú que puedes hacerlo desde allá arriba, porque yo me siento sordo»» [Rulfo, 2017: 228]. Scilicet, la sombra está constituida por un individuo, privado de uno de sus sentidos, el oído en este caso, que transporta a otro privado de movilidad. En el protagonista de nuestro cuento a la limitación del oído se une la parcial de la vista, ya que «no podía agachar la cabeza agarrotada entre las manos de su hijo» (Rulfo, 2017: 227). De ahí que el relato se articule sobre las reiteradas instancias del padre al hijo malherido para que mire, y sobre todo escuche, si hay signos de proximidad del ansiado destino, Tonaya, donde el padre podrá liberarse del oneroso peso e Ignacio ser atendido por un médico. Se trata del añejo mito del portador.

\section{El tópico del portador. Análisis comparado}

Este motivo, rastreable en diversas obras desde la Antigüedad hasta nuestros días, informa el tema nuclear de la novela El rey de los Alisos (Le Roi des Aulnes, 1970) de Michel Tournier, galardonada con el Goncourt ${ }^{12}$. Dedica un trabajo al asunto María Aurora Aragón Fernández (1983), y aunque en él no menciona en absoluto "No oyes ladrar los perros», el estudio posee interés para los exegetas de Rulfo: primero, porque profundiza en el tópico, al que la autora designa como la 'phorie' o el 'astróforo', cruzado con el del 'Gigante', y, en el tratamiento concreto que le confiere Tournier, con el del 'Ogro' ${ }^{13}$. En segunda instancia precisamente porque el artículo revela la universalidad y pervivencia de este

12 No hay espacio en los límites de este artículo para discriminar las acepciones de que pueden investirse los vocablos 'motivo', 'tópico' y 'tema', no pocas veces usados como sinónimos. Nos atenemos a lo expuesto en Montes Doncel, 2006: 17-22.

13 El ogro (Der Unhold, 1996) fue justamente el nombre que recibió el filme alemán que recrea esta novela, firmado por Volker Schlöndorff y protagonizado por John Malkovich. 
motus no particularmente pródigo. Nuestro análisis realizará lo que en Comparatismo se llama 'corte longitudinal o diacrónico', trazado desde los clásicos a la actualidad en distintas literaturas, por oposición al 'transversal o sincrónico', acotado a un periodo temporal concreto $^{14}$. Claudio Guillén (Guillén, 2005: 142) aplica a estos casos la terminología acuñada por Braudel para la historia de las sociedades: longues durées (duraciones largas), frente a moyennes durées (duraciones medias).

No existen rapports de fait entre El rey de los Alisos y el cuento de Juan Rulfo; es improbable, o al menos indemostrable a la luz de la lectura de la novela, que el autor francés conociese el opúsculo del mexicano ${ }^{15}$. Para la tematóloga Elisabeth Frenzel la diferencia entre argumento y motivo estriba en la constatación de nombres y datos que avalen la presencia de un tronco común, y en este sentido sí podemos hablar de un nexo que enraíza la obra francesa con Goethe, pues su título está tomado del de un poema del gran romántico alemán, «Erlkönig», que se abre con los versos: «Wer reitet so spät durch Nacht und Wind?/ Es ist der Vater mit seinem Kind;/ Er hat den Knaben wohl in dem Arm,/ Er faßt ihn sicher, er hält ihn warm» (Goethe, 1977: 115) ${ }^{16}$. La extensa balada, que también atrajo a Victor Hugo, y a la que pondría música Schubert entre otros autores, habla de un padre que lleva en brazos

14 Remitimos para estos conceptos a Cristina Naupert, 2001: 130-134.

15 El comparatista rumano Adrian Marino recalcaba que la ausencia de relaciones de hecho probadas añadía interés a la repetición de los fenómenos culturales: «[...] ils [ces phénomènes généraux] sont d'autant plus significatifs qu'ils sont détectés dans régions culturelles qui n'ont pas de rapports entre elles (influence, imitation, copie), dans des zones européennes et non-européennes sans contact historique» (Marino, 1988: 92). «[...] son tanto más significativos [estos fenómenos generales] cuando se detectan en regiones culturales que no tienen relaciones entre ellas (influencia, imitación, copia), en zonas europeas y no europeas sin contacto histórico» (Traducción nuestra).

16 «¿Quién tan tarde cabalga en la ventosa noche?/ Un padre con su hijo, a lomos del corcel;/ bien cogido lo lleva en sus brazos, seguro/ y caliente al recaudo de su regazo fiel» (Goethe, 1974: 850). 
a su pequeño hijo y que fracasa en su intento de salvarle de la acechante muerte. Tampoco puede afirmarse ni descartarse que Rulfo conociese la composición germana, por lo que vale hablar de argumento (terminología de Frenzel, 1976 y 1980) o tradición (terminología de Dámaso Alonso, 1985) en la relación que liga a Tournier con Goethe, mientras que no cabe alegar un tronco común entre Tournier y Rulfo ni entre Rulfo y Goethe, y en estos casos hablaríamos de motivo (Frenzel) o poligénesis (Alonso) ${ }^{17}$.

El protagonista Abel Tiffauges, cual portador negativo, rey de los Alisos, fue acusado en Francia de abuso de una menor, y recluta adolescentes en Prusia con destino a una napola nazi. Sin embargo, salva a un pequeño judío de nombre Éphraïm, y en el desenlace de la novela lo carga a sus espaldas para huir ante la llegada de los soviéticos. Asume entonces el papel de un portador positivo, Buen Pastor en la parábola del Nuevo Testamento (imagen ya evocada por Ángel Rama respecto a nuestro cuento), y aquí más concretamente portainfante, el San Cristóbal de la Leyenda aurea. Como el gigantón bajo el peso del Dios Niño, también Abel siente cual plomo sobre sus hombros al liviano Éphraïm, mientras él, que en cierto momento reconoce un aliso negro del pantano, se hunde cada vez más en el barro:

Peu à peu, le sol devaint spongieux sous ses pieds, et il devaint faire effort à chaque pas pour les arracher à sa succion. Puis ses mains rencontrèrent les branches et les troncs d'un petit bois, et il reconnut l'aulne noir des marécages. Il voulut s'arrêter, faire demitour, mais une force irresistible le poussait aux épaules. Et à mesure que ses pieds s'enfonçaient davantage dans la landèche gorgée d'eau, il sentait l'enfant - si mince, si diaphane pourtant- peser sur lui comme une masse de plomb (Tournier, 2007: 496).

17 Esta es la razón por la que en el análisis de dichos componentes temáticos en «No oyes ladrar los perros» preferimos no usar el término intertexto, como sí hace Pedro Lasarte, de cuyo trabajo hablaremos más adelante. Si pensamos en el sentido restringido de la voz intertexto (cfr. Montes Doncel y Rebollo Ávalos, 2006), no sería esta la terminología más adecuada para examinar el tópico del portador en el cuento de Rulfo. 
[Poco a poco, el suelo se iba haciendo esponjoso bajo sus pies, y a cada paso debía hacer un esfuerzo por arrancarlos de la succión. Después, sus manos tropezaron con las ramas y los troncos de un bosquecillo, y reconoció el aliso negro de los pantanos. Quiso detenerse, dar media vuelta; pero una fuerza irresistible gravitaba sobre sus hombros. Y a medida que sus pies se hundían más y más en el páramo empapado en agua, sentía que el niño - tan delgado, tan diáfano - pesaba encima de él como una masa de plomo] (Tournier, 1980: 501).

Por su parte, la relación de hecho o cadena de dependencia entre la novela francesa y la historia de San Cristóbal, Cristóforo, etimológicamente 'el que porta a Cristo', se encuentra sobradamente acreditada: señala Aragón, entre otros significativos detalles, que incluso el colegio en que Abel estudió de niño estaba bajo la advocación del Santo patrón de los viajeros.

Hay por otro lado un estudio que se ocupa del tópico en relación con el cuento de Juan Rulfo: nos referimos al de Pedro Lasarte, titulado ««No oyes ladrar los perros» de Juan Rulfo: peregrinaje hacia el origen», que acomete una búsqueda de los cultivadores antiguos y clásicos de este motus. Empieza Lasarte inventariando el más reconocible modelo, el episodio de la huida de Eneas de Troya llevando a hombros a su padre. Como sabemos, Anquises había engendrado al héroe de su relación con Venus, y cuando un mortal tenía amores con una diosa a veces lo pagaba con algún tipo de secuela física, en este caso la cojera. Asimismo el profesor de la Universidad de Boston recuerda un pasaje de la Antología griega en que se recoge un epigrama declamatorio (circa siglo XI) que habla de la pareja formada por un ciego que lleva a cuestas a un cojo, y cómo esta figura simboliza la caridad y fraternidad (Lasarte, 1989: 103). Igualmente interesante resulta la presencia del tópico, subrayada por Lasarte, en los emblemas publicados por Alciato en 1531. Bajo el lema «Que los hombres se an de favorecer unos a otros» aparece la pintura de ese portador ciego del inválido, a la que se adjuntan los versos que siguen: 
Infortunados de enfermedad

Diversa de sus cuerpos lastimados,

Mas tan conformes en la voluntad

Que a un mismo pareçer fueron llegados.

Conciértase que el que es de ceguedad

Enfermo al manco lleve, y concertados

Van por la vía a entrambos manifiesta,

Que no la vista, el otro los pies presta (Alciato, 1975: 75).

También menciona Lasarte el soneto sapiencial de Quevedo titulado «Significa la interesable correspondencia de la vida humana». Desarrolla el poeta barroco el tópico para elaborar un juego de antítesis y para mutar el concepto de clemencia en el de trueque:

El ciego lleva a cuestas al tullido:

dígola maña, y caridad la niego;

pues en ojos los pies le paga al ciego

el cojo, sólo para sí impedido.

El mundo en estos dos está entendido,

si a discurrir en sus astucias llego:

pues yo te asisto a ti por tu talego;

tú, en lo que sé, cobrar de mí has querido.

Si tú me das los pies, te doy los ojos:

todo este mundo es trueco interesado,

y despojos se cambian por despojos.

Ciegos, con todos hablo escarmentado:

pues unos somos ciegos y otros cojos,

ande el pie con el ojo remendado (Quevedo, 1963: 579).

Trasciende Quevedo los conocidos datos biográficos de la cojera y la acusada miopía del sujeto histórico en esa primera 
persona del plural del enunciado lírico. Y, volviendo a la emblemática de Alciato, una imagen de Eneas cargado con Anquises ilustra la frase «La piedad de los hijos para con los padres», y antecede a los versos que rezan:

Decía Eneas, quando por consejo

De Héctor con su padre hizo desvío

Quán poca gloria es vencer a un viejo

Tanta es librar al padre el hijo pío (Alciato, 1975: 128).

Cita Lasarte aún un último emblema de la celebérrima colección renacentista vinculado no ya al tópico del portador, sino al otro leit-motiv recurrente y medular del cuento de Rulfo. «Vano acometimiento» es su título, la pintura representa a un can que ladra a la luna, y la leyenda en tercetos alea a esta figura con un clamor infructuoso.

La luna el perro de noche está mirando.

Vese (como de espejo en un aliento)

Y cómo a otro perro está ladrando.

Pero en vano sus voces echa al viento

Que la sorda Diana no escuchando

Continúa su correr y movimiento (Alciato, 1975: 273).

El crítico peruano sustenta su interpretación del cuento en la simbología aportada por este tercer emblema y en el concepto mexicano de tonalli (semejante al de destino), y postula que el viaje del caminante con su carga ha sido inútil, ergo, que el padre no consigue salvar a Ignacio.

Lasarte no se ocupa, sin embargo, del cultivo del tema en autores contemporáneos. El tópico mantiene su vigencia, como demuestran El rey de los Alisos de Tournier y el propio relato de Rulfo, pero todavía pueden agregarse bastantes más ejemplos, entre los que hemos seleccionado cinco: en la narrativa decimonónica el famoso y monumental folletín Los miserables (Les misé- 
rables, 1862) de Victor Hugo, que de tantas transposiciones fílmicas y musicales ha sido objeto; en el siglo XX las novelas Sin novedad en el frente (In Westen nichos Neues, 1929) de Erich Maria Remarque y La impaciencia del corazón, también traducida al español como La piedad pilagrosa (Ungeduld des Herzens, 1939), del austriaco Stephan Zweig; y ya en nuestro siglo el cuento de Fernando Aramburu «El hijo de todos los muertos», perteneciente al libro Los peces de la amargura (2006), y el filme El caballo de dos piernas (Asbe du-pe, L'enfant cheval, 2008), de la realizadora Samira Mackhmalbaf, cinta de nacionalidad franco-iraní rodada en Afganistán.

La obra de Victor Hugo tiene por protagonista al casto y abnegado Jean Valjean, epítome de héroe folletinesco. En la primera parte de la novela Jean Valjean ejerce de portainfante huyendo con la pequeña huérfana Cosette en brazos, primero de la familia Thenardier, que maltrataba a la niña, y después del protervo inspector Javert, cuyo propósito es encarcelar al protagonista, convicto fugado (propósito que, de cumplirse, privaría a la niña de su único protector y la devolvería a la miseria de la que este la había sacado). Pero aún más ceñida al motivo que nos ocupa se encuentra la segunda de sus modulaciones en la obra: años más tarde Cosette, convertida en una hermosa joven, se enamora de un guapo y apasionado muchacho llamado Marius y es correspondida por él. Marius no dispone de bienes propios de fortuna $\mathrm{y}$, convencido de que su matrimonio con Cosette es imposible, se une a las barricadas parisinas de junio de 1832 dispuesto a morir. Jean Valjean, por azar ínsito al folletín, intercepta la correspondencia de los jóvenes; pese a que la muerte de Marius convendría a sus intereses egoístas de retener a Cosette, penetra en las barricadas y forma con los combatientes con el único fin de proteger la vida de Marius si la situación lo requiriese. La situación lo requiere, porque muchas páginas más adelante Marius recibe un balazo y queda inconsciente. El corpulento Jean Valjean, cuya fortaleza física aneja a la moral ha sido remarcada no pocas veces a lo largo de la novela (acaba de perdonarle la vida al pertinaz 
Javert, que aún le perseguía), carga con el herido y escapa por el único camino posible, el laberinto subterráneo y nauseabundo de las alcantarillas de la ciudad. Victor Hugo no nos ahorra una digresión de seis capítulos (libro segundo de la quinta y última parte) sobre las cloacas parisinas y su historia, pero tras su gesta Jean Valjean logra sacar vivo a Marius a la superficie y devolverlo a los suyos para que se recupere.

La novela de culto antibelicista de Erich Maria Remarque narra por boca de un relator homodiegético, Paul, las durísimas condiciones de vida en el frente de un grupo de siete jóvenes alemanes, casi niños, que se alistan para participar en la 1aㅡ Guerra Mundial, algunos alentados por un profesor del instituto. El motivo del portador se localiza en la última sección del undécimo y penúltimo capítulo, cuando toda esperanza de ganar la guerra se ha desvanecido y los soldados solo sueñan con el armisticio que les permita regresar vivos: han muerto ya todos los integrantes del grupo (que fueron cayendo a lo largo del relato en orden inverso a su grado de intimidad con Paul), excepto el protagonista y su mejor amigo, Katczinsky (alias Kat), el más individualizado de los personajes ${ }^{18}$. Los dos muchachos van a buscar víveres, Kat cae herido y se rompe la pierna. Se preguntan hasta qué punto no será esta una coyuntura afortunada, pues Kat ya no podrá volver a las trincheras antes de que la guerra termine. Paul llega a calibrar incluso el provocarse él también una lesión en el pie. Como van a separarse se intercambian sus direcciones y el protagonista carga a cuestas con su amigo hasta el puesto de socorro, corriendo «einen gedehnten, langsamen Dauerlauf, damit sein

18 «-Ich bin sehr traurig, es ist unmöglich, daß Kat - Fat, mein Freud, Kat mit den Hängeschultern und dem dünnen, weichen Schnurrbart, Kat, den ich kenne auf eine andere Weise als jeden anderen Menschen, Kat, mit dem ich diese Jahre geteilt habe-, es ist unmöglich, daß ich Kat vielleicht nicht viedersehen soll» (Remarque, 1998: 194). [Es imposible que Kat —mi amigo Kat, el de los hombros caídos y el bigotito ralo; Kat, a quien conozco de forma muy distinta a cualquier otra persona; Kat, con quien he convivido estos años-, es imposible que no vuelva a ver a Kat] (Remarque, 2009: 250). 
Bein nicht zu sehr schlenkert» (Remarque, 1998: 194) ${ }^{19}$ al herido. El enfermero lo recibe con estas palabras: «»Das hättest du dir sparen können» (Remarque, 1998: 195) ${ }^{20}$. Paul y Kat habían estado hablando tan solo diez minutos antes, pero en ese intervalo el segundo ha recibido un impacto de metralla en la cabeza.

La impaciencia del corazón está narrada y protagonizada por el teniente de ulanos Tony Hofmiller, de quien está enamorada una muchacha inválida llamada Edith de Kekesfalva. Una noche de desvelo Tony lee un cuento en una edición de Las mil y una noches que en una ocasión compró a un vendedor ambulante solo por lástima, ya que no es aficionado a la lectura:

[...] Ich las die Anfangsgeschichte von Scheherezade und dem König mit matter Aufmerksamkeit und dann weiter und weiter. Aber plötzlich schrak ich auf. Ich war auf das merkwürdige Märchen gestoßen von jenem jungen Mann, der am Wege einen lahmen Greis liegen sieht, und bei diesem einen Worte "gelähmt» zuckte etwas in mir empor wie ein scharfer Schmerz; ein Nerv war von der plötzlichen Assoziation wie von einem Brandstrahl berührt. Der gelähmte Greis ruft in jenem Märchen den jungen Menschen verzweifelt an, er könne nicht gehen und ob er ihn nicht auf seine Schultern aufsitzen lassen wolle und weitertragen. Und der junge Mann hat Mitleid - Mitleid, du Narr, warum hast du Mitleid? dachte ich mir -, er beugt sich wirklich hilfreich nieder und setzt sich den alten Mann huckepack auf den Rücken.

Aber dieser scheinbar hilflose Greis ist ein Djinn, ein böser Geist, ein schurkischer Zauberer, und kaum daß er dem jungen Menschen auf den Schultern sitzt, klemmt er plötzlich seine haarigen nackten Schenkel nervig um die Kehle seines Wohltäters und ist nicht mehr abzuschütteln. Unbarmherzig macht er den Hilfreichen zu seinem Reittier, er peitscht, der Rücksichtslose, der Mitleidlose,

19 «a un ritmo moderado para que no se le bambolee demasiado la pierna» (Remarque, 2009: 250).

20 «-Podías haberte ahorrado el trabajo» (Remarque, 2009: 251). 
den Mitleidigen weiter und weiter, ohne ihm Rast zu gönnen. Und der Unselige muß ihn tragen, wohin jener es heischt, er hat von nun ab keinen eigenen Willen mehr. Er ist das Reittier, ist der Sklave des Elenden geworden, und ob ihm auch die Knie wanken und die Lippen verschmachten, er muß, der Narr seines Mitleids, fort und fort traben und den bösen, den verruchten, den listigen alten Mann als sein Schicksal auf dem Rücken schleppen.

Ich hielt inne. Das Herz schlug mir, als wollte es aus der Brust springen. Denn noch während ich las, hatte ich plötzlich in einer unerträglichen Vision diesen listenreichen fremden Greis gesehen, wie er erst auf der Erde lag und tränend die Augen aufschlug, um von dem Mitleidigen Hilfe zu erflehen, ihn gesehen, wie er dann huckepack dem andern auf dem Rücken saß. Er hatte weißes gescheiteltes Haar, jener Djinn, und trug eine goldene Brille. Mit der ganzen Blitzhaftigkeit, mit der sonst nur Träume Bilder und Gesichter heranzureißen und zu vermengen verstehen, hatte ich dem Greise des Märchens instinktiv Kekesfalvas Gesicht geliehen, und ich war mit einmal selbst das unselige Reittier geworden, das er peitschte und vorwärtspeitschte, ja, ich fühlte um die Kehle den Druck so körperlich, daß mir der Atem stockte. Das Buch fiel mir aus den Händen, ich blieb liegen, eiskalt, und hörte mein Herz an die Rippen pochen wie an hartes Holz; noch durch den Schlaf jagte dieser grimmige Jäger weiter und weiter, ich wußte nicht wohin. Als ich morgens mit nassem Haar erwachte, war ich erschöpft und ausgemüdet wie nach unermeßlichem Weg (Zweig, 1994: 243-244).

[...] Leí el comienzo de la historia de Sherezade y el rey con atención fatigada, y seguí leyendo y leyendo. Pero, de pronto, me sobresalté. Había llegado al extraño cuento del joven que ve tendido en el camino a un anciano tullido, y al leer esta palabra, «tullido», algo así como un dolor agudo me hizo dar un respingo; como un leño ardiendo, la repentina asociación de ideas me había tocado un nervio. En la historia, el anciano tullido llama desesperado a un joven, le dice que no puede caminar y le pide que lo lleve a hombros. Y el joven siente compasión -compasión, necio, ¿por qué 
sientes compasión?, pensé-, en efecto se inclina caritativo y sube al viejo a cuestas.

Pero el anciano en apariencia desvalido era un djin, un espíritu maligno, un mago infame, y apenas se sentó en los hombros del joven, apretó con fuerza sus muslos peludos y desnudos alrededor de la garganta de su benefactor, quien ya no pudo quitárselo de encima. Implacable, convirtió al caritativo joven en su montura; el cruel y despiadado viejo siguió pegando al compasivo joven sin darle reposo. Y el desdichado se vio obligado a llevarlo a donde el otro quería y desde entonces quedó desposeído de voluntad propia. Se convirtió en la cabalgadura, en el esclavo del miserable viejo, y aunque las rodillas le flaquearan y los labios se consumieran de sed, ese loco de la compasión tuvo que seguir trotando y trotando y llevar a cuestas como a su destino al malvado, astuto e infame viejo.

Me detuve. El corazón me latía como si quisiera saltar del pecho, pues, mientras leía, de repente vi en una visión insoportable al desconocido y astuto viejo, lo vi primero tendido en el suelo y levantando los ojos llenos de lágrimas para implorar ayuda al compasivo joven, y lo vi después montado sobre sus hombros. Aquel djin tenía el pelo blanco, peinado con raya al medio, y llevaba gafas doradas. Con la misma rapidez con que sólo los sueños saben evocar y mezclar imágenes y rostros, instintivamente había atribuido al anciano del cuento el rostro de Kekesfalva y yo mismo me había convertido de pronto en la infeliz cabalgadura, que él azuzaba con el látigo, e incluso sentía tan real la presión alrededor de la garganta, que se me cortó la respiración. Me cayó el libro de las manos, me quedé tendido, frío como el hielo, y oí los latidos de mi corazón golpeando las costillas como contra madera dura; y todavía durante el sueño la furibunda carrera prosiguió a todo galope, no sabía hacia dónde. Cuando me desperté al día siguiente con los cabellos empapados, estaba cansado y exhausto como después de una larga caminata] (Zweig, 2016: 247-249).

El acaudalado Señor de Kekesfalva, padre de Edith, suplica y presiona a Tony para que ayude su hija, de modo que aquí el 
tópico actúa en calidad de intertexto (el episodio atribuido a la tradición árabe, combinado con el longevo recurso del sueño) y de explícita mise en abyme, por cuanto el metarrelato refleja la acción principal y sus accidentes, como observa el propio personaje, y como volverá a apuntarse en otros momentos de la novela ${ }^{21}$. En la obra del escritor austriaco el mito del portador sirve para simbolizar una derivación de la solidaridad: 'la piedad peligrosa', expresión que precisamente dio título a una traducción de la novela en castellano. El lisiado se convierte en el tirano del portador.

21 Cuando Edith lo acosa con continuas cartas: «Noch ein Brief! Noch ein zweiter, innerhalb von zwei Stunden! Sofort pappt sich mir die Kehle zu mit Ärger und Zorn. So wird das jetzt jeden Tag weitergehen, jeden Tag, jede Nacht, Brief auf Brief, einer nach dem andern. Wenn ich ihr schreibe, wird sie mir wieder schreiben, wenn ich nicht antworte, wird sie Antwort fordern. Immer wird sie etwas von mir wollen, jeden Tag, jeden Tag! Sie wird mir Boten schicken und mich antelephonieren, sie wird mich umlauern und umlauern lassen bei jedem Schritt, wird wissen wollen, wann ich ausgehe und zurückkomme, mit wem ich bin und was ich sage und tue und treibe. Ich sehe schon, ich bin verloren - sie lassen mich nicht mehr los - oh, der Djinn, der Djinn, der Alte und der Krüppel! Nie werde ich mehr frei sein [...]» (Zweig, 1994: 300). «¡Otra carta! ¡Dos cartas en dos horas! Al instante se me hace en la garganta un nudo de rabia e indignación. Eso será así todos los días ahora, todos los días y todas las noches, una carta tras otra. Si le escribo, volverá a escribirme; si no le contesto, me exigirá una respuesta. Siempre querrá algo de mí, todos los días, ¡todos los días! Me mandará mensajeros, me llamará por teléfono, espiará y hará espiar cada paso mío, querrá saber cuándo salgo y cuándo vuelvo, con quién estoy y qué digo y hago y mi vida y milagros. Veo que estoy perdido..., ya no me soltarán... ¡Ah, el djin, el djin, el viejo lisiado! Nunca más volveré a ser libre [...]» (Zweig, 2016: 305). Y cuando Kekesfalva vuelve a implorarle ayuda, arrodillándose incluso ante Tony: «»Sie müssen ihr helfen ... nur Sie können ihr helfen, nur Sie ... auch Condor [el médico] sagt es: nur Sie und kein anderer! ... ich flehe sie an, erbarmen Sie sich ... es geht nicht so weiter ... sie tut sich sonst etwas an, sie richtet sich selbst zugrunde./ So sehr mir die Hände beben, ich reiße den Hingeknieten gewaltsam wieder empor. Aber er packt meine helfenden Arme, wie Krallen spüre ich die verzweifelt angepreßten Finger in meinem Fleisch - der Djinn, der Djinn meines Traums, der den Mitleidigen vergewaltigt» (Zweig, 1994: 383). «-Tiene que ayudarla..., sólo usted puede ayudarla, sólo usted... También Condor lo dice: justed y nadie más...! Se lo suplico, tenga compasión..., no puede seguir así..., de lo contrario cometerá algún desatino, se perderá./ A pesar de que las manos me tiemblan, obligo al anciano a levantarse, pero él sigue aferrándose a los brazos que intentan ayudarle; siento en mi carne sus dedos desesperadamente atenazadores como garfios... Es el djin, el djin de mis sueños, que abusa del compasivo» (Zweig, 2016: 389). 
Fernando Aramburu, último Premio Nacional de Narrativa por Patria, había publicado ya en 2006 una serie de relatos sobre las víctimas del terrorismo etarra que contenían embrionariamente temas más tarde desarrollados en su gran éxito editorial (por citar solo uno de los más evidentes, la etopeya de la fanática madre del etarra y los motivos que la circundan en «Maritxu», que prefigura al personaje de Miren). «El hijo de todos los muertos» se centra en el adolescente Íñigo, cuyo padre, José Manuel, fue asesinado por un comando al que pertenecía una etarra de su propia localidad llamada Karmele. El anciano padre de José Manuel fue en su juventud amigo de Kinito, el padre de la asesina, y, en contra de la consigna de omertá impuesta por la viuda para proteger al chico, cuenta a su nieto cómo él salvó la vida de Kinito durante la Guerra Civil. Abuelo y nieto mantienen esta conversación mientras ven desde la ventana a Kinito, presente en una manifestación de homenaje a Karmele que el pueblo ha organizado para festejar que ha sido excarcelada. Íñigo reproduce el relato del abuelo:

Entonces el aitona saltó por una ventana y se fue de la ciudad y se encontró a Kinito tirado en la carretera con la pierna rota. Se había quedado solo, sin poder moverse y, según el aitona, llorando como un crío. Los dos tenían dieciocho años. Bueno, pues el aitona cargó con Kinito al hombro como si sería un saco y pasó con él a nado el Bidasoa. Mira, Íñigo, mira cómo no se atreve a mirar para aquí, me dice el aitona. Se le debería caer la cara de vergüenza. Yo le salvé a él, el 4 de septiembre, nunca lo olvidaré y él tampoco lo habrá olvidado (Aramburu, 2006: 199-200).

El tópico del portante compone una modalidad meritoria de la acción de salvar la vida a un individuo, ya pariente o amigo (Eneas-Anquises, padre-niño en «Erlkönig», Paul-Kat), ya oponente en algún grado (Jean Valejean-Marius, Tiffauges-Éphraïm, padre-Ignacio) $)^{22}$. Aquí la relación se torna también problemática,

22 Irónicamente, en «Talpa» el narrador y su cuñada Natalia transportan penosamente a Tanilo, hermano del primero, para tratar de conducirlo a la muerte en 
pues quienes eran amigos cuando acaece la peripecia se transforman después en antagonistas. Es este el enfoque esencial que adopta Patria, construyendo una ficción en la que existe inicialmente intimidad y apego entre la familia de la víctima y la del asesino. Uno de los temas útiles a tal propósito consiste precisamente en que el occiso o uno de los suyos haya salvado la vida, y de forma esforzada (como portador), al futuro criminal o a un allegado, y tal hecho constituye el motivo estelar en «El hijo de todos los muertos». Ignoro si el autor vasco tenía in mente el caso real de Ramón Baglietto, asesinado en Azcoitia en 1980 por Cándido Azpiazu, a quien él había librado de morir cuando el terrorista era un niño de corta edad. Ello ocurrió en el transcurso de un accidente de tráfico en el que Baglietto sujetó a Azpiazu, por lo que apenas si puede decirse que actuara como portador unos momentos: el tópico, con sus formantes novelescos, es lo que Aramburu toma del acervo literario y no de la realidad.

La película El caballo de dos piernas, que dirige una de las hijas de la familia de cineastas iraníes Makhmalbaf, despliega por su parte una anécdota más parecida a la de La impaciencia del corazón: un chico deficiente mental es contratado por un padre para transportar a su hijo, un niño más pequeño que ha quedado mutilado por una mina antipersonal y que lo que realmente desearía es adquirir un caballo. Los cien minutos de duración del filme se hacen más tediosos que las mil páginas de media de cualquier edición de Los miserables, y esto viene a dar la razón a Baquero Goyanes cuando afirmaba que ciertos temas que informan el cuento no son aptos para la novela ${ }^{23}$. Lo que podría ser, y de hecho es en «No oyes ladrar los perros», armazón temático de un excelente cuento, o de un episodio de ciertas narraciones

vez de a la vida: «Tanilo se nos caía más seguido y teníamos que levantarlo y a veces llevarlo sobre los hombros» (Rulfo, 2017: 157).

23 Por ejemplo, los seres y objetos pequeños. «[...] una aparente minucia - un objeto insignificante- se carga de trascendencia» (Baquero Goyanes, 1988: 154). Él allega los casos de «El encaje roto» de Emilia Pardo Bazán o «Por un piojo» de Coloma. «El estornudo» de Chéjov también ilustra excelentemente esa idea. 
largas (desde la Eneida de Virgilio a Sin novedad en el frente), se torna a todas luces limitado como eje para apuntalar la historia de un relato más extenso. Esta selección desacertada aboca a la película iraní a una cansina e indeseable reiteración. Samira Mackhmalbaf por cierto ha sido reconocida por la crítica y obtuvo el Premio Especial del Jurado del Festival de San Sebastián en 2008 por esta obra, pero diríase que pasa con ella lo contrario que con su compatriota Farhadi, quien cuente lo que cuente consigue no aburrir nunca (al menos hasta llegar a su último trabajo, Todos lo saben, que parece dirigido por un discípulo poco aprovechado del autor de Nader y Simin).

Hemos apreciado que el tópico registra variantes. Ya observó Lasarte que la pareja está invertida en Rulfo respecto al dechado virgiliano, pues mientras Eneas sostiene a su padre, en el cuento es el padre quien sostiene al hijo. Algunas veces, la mayoría, el amor paterno-filial o la amistad guían esta conducta, mientras que en el presente caso las relaciones entre padre e hijo se describen como negativas. La animosidad de Jean Valjean hacia Marius suma mérito a su hazaña, y en Tiffauges la acción adquirirá matices expiatorios; La impaciencia del corazón y El caballo de dos piernas muestran el papel no ya calculador (recordemos a Quevedo), sino incluso despótico, que puede desempeñar el débil, y en «El hijo de todos los muertos» el tópico sirve al propósito de ejemplificar la ingratitud y vesania en que llegan a incurrir los etarras. De la misma forma, este sacrificio puede conducir a la salvación del portado (Jean Valjean-Marius), o puede convertirse en un esfuerzo inútil, y en nuestro caso nos inclinamos a pensar que la llamada por Zirmunskij «lógica del tratamiento del tema» (apud Frenzel, 1980: IX) gravita más del lado de la muerte, que presentimos cercana en el poema de Goethe, en la novela de Remarque y, desde luego, en el cuento de Rulfo. Solo así el motivo deviene metáfora del afán inútil del ser humano, del mismo modo, por ejemplo, que la simbólica persecución del pez por parte de Santiago en El viejo y el mar (The Old Man and The Sea) de Hemingway, o la espera de Godot. ¿Cuál es el caso de «No 
oyes ladrar los perros»? ¿Qué sugiere el texto? Algunos autores, como Graciela C. Coulson, insinúan que Ignacio vive, que el ladrido anuncia la tierra prometida (Coulson, 1971: 164), mientras que la mayoría, como Donald K. Gordon (Gordon, 1976), y Lasarte (Lasarte, 1989), por las razones expuestas, son partidarios de pensar que el herido llega muerto a Tonaya. Se contabilizan diversos indicios, que no pruebas concluyentes, generadoras de esa sospecha: no solo el prolongado silencio de Ignacio en la última parte del discurso; también leemos que el protagonista «[s] intió que el hombre aquel que llevaba sobre sus hombros dejó de apretar las rodillas y comenzó a soltar los pies, balanceándose de un lado para otro» (Rulfo, 2017: 228), y justo antes del cierre, que «destrabó difícilmente los dedos con que su hijo había venido sosteniéndose de su cuello [...]» (Rulfo, 2017: 229).

\section{Hacia una interpretación del cuento}

Además subyace en el texto una simbología en la que no han reparado los trabajos por nosotras conocidos: la creencia popular y muy extendida de que los perros laten a la muerte, presienten la muerte, e incluso mueren a veces cuando mueren sus amos. Recordemos, entre los reflejos literarios de este tópico, el desenlace de La familia de Alvareda, novela de la folklorista Fernán Caballero, o el de Niebla de Unamuno, y los ladridos de los perros en el famoso poema «Insomnio» de Dámaso Alonso, en el que el campo semántico de la muerte (cementerio, cadáveres) designa a Madrid y a sus habitantes. En Réquiem por un campesino español se especifica que inmediatamente antes de la muerte del protagonista «se oían ladrar los perros y sonaba una campana» (Sender, 2018: 143), y, en Crónica de una muerte anunciada, se dice que los hermanos Vicario, asesinos de Santiago Nasar, salen a su encuentro "con los cuchillos sin envolver, perseguidos por el alboroto de los perros en los patios» (García Márquez, 1982: 100). La literatura trivial y reciente sigue haciéndose eco de esta creencia, y así empieza El corazón del tártaro, de la hoy laureada con el Premio Nacional de Letras Rosa Montero: «Lo peor es que 
las desgracias no suelen anunciarse. No hay perros que ululen al amanecer señalando la fecha de nuestra muerte, y uno nunca sabe, cuando comienza el día, si le espera una jornada rutinaria o una catástrofe» (Montero, 2001: 11). Dentro de la colección de Rulfo, en el último párrafo del cuento «En la madrugada» leemos, tras producirse la muerte violenta de Don Justo Brambila: «Esa noche no encendieron las luces, de luto, pues don Justo era el dueño de la luz. Los perros aullaron hasta el amanecer» (Rulfo, 2017: 150). Al margen de esto, 'oír ladrar los perros' es en México una fórmula habitual para indicar la cercanía de una persona o una población ${ }^{24}$.

La pregunta reiterada por el ladrido de los perros por parte del padre, justificada en su transitoria sordera, se vuelve así pertinente. Manifiesta, en un primer nivel, angustiosa interrogación por tener signos de la proximidad de Tonaya y, al mismo tiempo y metafóricamente, está inquiriendo: ¿Ignacio, vas a morir? La respuesta, el final en punta normativo del género («- ¿Y tú no los oías, Ignacio? - dijo- . No me ayudaste ni siquiera con esta esperanza» [Rulfo, 2017: 229]), no contradice esta interpretación, dado que el portador había declarado paladinamente no amar a su hijo. Las relaciones paterno-filiales conflictivas podrían considerarse, de hecho, 'mito personal' (Mauron, 1986), 'tema de identidad' (Holland, 1975 y 1976) o 'afinidades personales'

24 Así por ejemplo, leemos en la primera página del primer cuento de El Llano en llamas, «Nos han dado la tierra»: "Después de tantas horas de caminar sin encontrar ni una sombra de árbol, ni una semilla de árbol, ni una raíz de nada, se oye el ladrar de los perros [...] Hay un pueblo. Se oye que ladran los perros [...]» (Rulfo, 2017: 109); y en la última: «Ahora los ladridos de los perros se oyen aquí, junto a nosotros, y es que el viento que viene del pueblo retacha en la barranca y la llena de todos sus ruidos» (Rulfo, 2017: 115). Y en el segundo relato, «La cuesta de las comadres»: «Luego volvían los Torricos. Avisaban que venían desde antes que llegaran, porque sus perros salían a la carrera y no paraban de ladrar hasta encontrarlos. Y nada más por los ladridos todos calculaban la distancia y el rumbo por donde irían a llegar» (Rulfo, 2017: 119); «Ese aire que sopla tantito antes de la madrugada se llevó los gritos de su canción y ya no pude saber si me seguían, hasta que oí pasar por todos lados los ladridos encarrerados de sus perros» (Rulfo, 2017: 121). 
(Trousson, 1981) en Rulfo ${ }^{25}$. Nos suministra claves en este sentido el conocimiento global de la producción del autor jalisciense; el lector atento y competente evocará que en «iDiles que no me maten!» quien vigila a Juvencio Nava antes de su ajusticiamiento y se niega a ayudarle es su propio hijo, Justino, que se hace cargo del cadáver y se lo lleva cargado en un burro en el desenlace del relato, animado no sabemos exactamente por qué sentimiento, pues son ambiguas las palabras de este personaje que cierran el cuento. «Paso del Norte» presenta por su parte una actitud de despego del padre hacia el hijo, y aun en las historias en que la relación entre vástago y progenitor no es negativa, el homicidio de uno de ellos suele constituirse en motor de sangrienta venganza. «Diles que no me maten!» supone una muestra de ello: el coronel que condena a Juvencio Nava lo hace porque este mató a su padre, Guadalupe Terreros, que le negó el pasto para sus animales, y el perseguidor de «El hombre» parece, según se desprende de sus soliloquios, más movido por vengar a su hijo que a su esposa.

«El Llano en llamas», la más larga de las relaciones del libro, termina con el descubrimiento por parte del narrador-protagonista, Pichón, de un hijo ya crecido cuyo rictus de maldad hace que el bandolero se vea reflejado en su propia estirpe. En cuanto a «La herencia de Matilde Arcángel», repite el motivo de conclusión de «iDiles que no me maten!». El hijo que, suponemos, ha permitido la muerte del padre o ha participado en ella (el episodio se halla elíptico del discurso) regresa a casa transportando en una cabalgadura el cadáver del interfecto. Euremio Cedillo padre había maltratado durante toda su vida al chico, al que consideraba culpable de haber propiciado la muerte de su madre, Matilde Arcángel ${ }^{26}$.

25 Françoise Perus revisa los temas del conflicto padre-hijo y, asociado o no con este, el del incesto, en su reciente edición de El Llano en llamas (Rulfo, 2017: 26-35).

26 Viene aquí a las mientes la presencia de este mismo motivo en Cumbres borrascosas (Wuthering Heigths), la famosa y a nuestro juicio sobrevalorada novela de Emily Brontë. Heathcliff, guiado por el rencor igual que Euremio, se conduce de 
A todo ello hay que añadir, evidentemente, la relación visionaria del narrador de Pedro Páramo, Juan Preciado, con el padre al que no conoció, y su diálogo a veces post mortem con mujeres -Dorotea, Eduviges y Susana-, que pudieron haber sido sus madres: la primera porque vivió buscando un hijo (fragmento 36) de la misma manera que Juan buscaba a su padre, la segunda porque quiso a Pedro Páramo y la tercera porque Pedro Páramo la quería a ella.

Huelga apuntar aquí el hecho histórico, de todos conocido, del asesinato del padre de Rulfo, que aunque muchos contextualizan en la Guerra de los Cristeros al parecer poco tuvo que ver con esta ${ }^{27}$. En 1923, cuando el futuro escritor era un niño de seis años de edad, Juan Nepomuceno Rulfo, apodado Cheno, fue tiroteado por la espalda por un individuo, de nombre Guadalupe Nava, que quería atravesar con su ganado las tierras de Rulfo y que se había enfrentado con él por dicha cuestión. Esta tragedia determinó la vida del novelista, quien tras perder también prematuramente a su madre sufrió la desintegración familiar. Por supuesto, el acontecimiento circula asimismo por sus escritos literarios, hasta el punto de que siguiendo una terminología psicoanalítica podríamos catalogarlo, como antes apunté, de 'mito personal' o 'tema de identidad': basta repasar los nombres de víctima y victimario y el origen del conflicto en «iDiles que no me maten!».

Toda la obra ficcional de Rulfo se localiza de hecho en una fantasmagórica y árida llanura que tiene por Marco de Referen-

forma despiadada y violenta con Hareton, hijo de su enemigo de juventud Hinley Earnshaw, y desprecia a Linton, que es su propio hijo, pero habido de su matrimonio con Isabella y no de Catherine Earnshaw, la mujer a la que Heathcliff amaba. Heathcliff y Catherine se dirían los antepasados victorianos de Pedro Páramo y Susana San Juan. El berroqueño protagonista de Cumbres borrascosas también se enamora en su niñez, cuando es pobre, de una joven a la que no olvidará cuando se vuelve poderoso y rico, ni cuando se casa por interés o tiene un hijo con otra mujer. Y la figura femenina idolatrada, que también aquí muere antes que su infatigable enamorado, también curiosamente 'habla desde la tumba'. 
cia Externo (expresión de Benjamin Harshaw, 1997) su Jalisco natal, aunque el autor vivió la mayor parte de su vida en México D. F. En cualquier caso, Rafael Olea señala atinadamente que «como sagaz creador que él era, nunca usó ningún elemento autobiográfico sin antes pasarlo por un exigente tamiz de coherencia» (Olea, 2007: 21).

\section{Conclusión}

Siguiendo los procedimientos y terminología de la Literatura Comparada, este trabajo analiza «No oyes ladrar los perros» de Juan Rulfo dirimiendo en primer lugar los constituyentes de género del cuento en él discernibles (territorio comparatista de la Genología) y cotejándolos con los del género narrativo mayor, la novela, y con los de la lírica. Al estudio pragmático se suman los resortes de la disciplina narratológica y, por otro lado, partimos del texto rulfiano para describir un recorrido del tópico literario que vertebra esta historia, el tópico del portador, por diferentes épocas y literaturas; establecemos pues un corte de tipo longitudinal o diacrónico. Otros críticos han realizado ya incursiones en el cultivo del portante entre clásicos y clasicistas, por lo que nosotras hemos seleccionado un corpus de autores contemporáneos (siglos XIX, XX y XXI): la colación del tratamiento y desempeño de un tópico o motivo en distintos autores, que permite extraer sus invariantes, se inscribe a su vez en el campo comparatista de la Tematología. Por último, agavillando los resultados de estos métodos y otra posible clave hermenéutica que se asienta en un símbolo atávico (el encaje entre el ladrar de perros y la muerte), y explorando la presencia en el relato de uno de los temas recurrentes de Rulfo (las relaciones paterno-filiales conflictivas), aspiramos a haber arrojado alguna luz nueva sobre su correcta interpretación.

\section{Referencias bibliográficas}

Alciato, Andrea. ([1531] 1975) Emblemas, Madrid, Editora Nacional, traducción al español de Bernardino Daza Pinciano, 
prólogo de Manuel Montero Vallejo, preparación de textos y notas de Andrés Soria.

Alonso, DÁmaso. (1985) «¿Tradición o poligénesis?», Estudios varios, Madrid, Gredos, 707-731.

Aragón Fernández, María Aurora. (1983) «La dimensión mitológica de Le Roi des Aulnes de Michel Tournier», Archivum, XXXIII, 29-50.

Aramburu, Fernando. (2006) «El hijo de todos los muertos», Los peces de la amargura, Barcelona, Tusquets, 179-201.

Baquero Goyanes, Mariano. (1988) Qué es el cuento, Murcia, Universidad.

Cierlina, Paulina. (2016) Rasgos significativos de la oralidad en la narrativa breve hispanoamericana: Juan Rulfo, Universidad Complutense de Madrid, tesis doctoral.

Coulson, Graciela B. (1971) «Observaciones sobre la visión de mundo en los cuentos de Juan Rulfo (a propósito de «Talpa» y «No oyes ladrar los perros»)», Nueva narrativa hispanoamericana, 2, 159-166.

Eichenbaum, Boris. ([1925] 1991) «Sobre la teoría de la prosa», en Todorov, T., Teoría de la literatura de los formalistas rusos, México, Siglo Veintiuno, 147-157.

Escandell, María Victoria. (1993) Introducción a la pragmática, Barcelona, Anthropos.

Espronceda, José De. (1990) Poesías líricas y fragmentos épicos, Madrid, Castalia, edición de Robert Marrast.

Fontanier, Pierre. ([1825-30] 1977) Les Figures du Discours, París, Flammarion.

Frenzel, Elisabeth. ([1970] 1976) Diccionario de argumentos de la literatura universal, Madrid, Gredos.

Frenzel, Elisabeth. ([1976] 1980) Diccionario de motivos de la literatura universal, Madrid, Gredos.

Friedman, Norman. ([1955] 1967) «The Point of View in Fiction», en Stevick, P., The Theory of the Novel, Nueva York, The Free Press, 108-137. 
García Márquez, Gabriel. (1982) Crónica de una muerte anunciada, Barcelona, Bruguera.

Genette, Gérard. (1969) Figures II, París, Seuil.

Genette, Gérard. (1972) Figures III, París, Seuil.

Goethe, Johan Wolfgang Von. (1977) Sämtliche Werke, Zurich, Artemis-Verlag-AG, Band 1. Traducción española: Obras completas, traducción de Rafael Cansinos Assens, Madrid, Aguilar, 1974.

Gordon, Donald K. (1976) Los cuentos de Juan Rulfo, Madrid, Playor.

Guillén, Claudio. ([1985] 2005) Entre lo uno y lo diverso. Introducción a la Literatura Comparada (Ayer y hoy), Barcelona, Tusquets.

Harshaw, Benjamin. (1997) «Ficcionalidad y campos de referencia», en Garrido Domínguez, A., Teorías de la ficción literaria, Madrid, Arco/Libros, 123-157.

Holland, Norman. (1975) «Unity Identity Text Self», PMLA, 90.5, 314-422.

Holland, Norman. (1976) «Transactive Criticism: Re-Creation Through Identity», Criticism, 18, 334-352.

INGARDEN, Roman. (1989) «Concreción y reconstrucción», Warning, W., Estética de la recepción, Madrid, Visor, 33-53.

Kunz, Mario. (1997) El final de la novela. Teoría, técnica y análisis del cierre en la literatura moderna en lengua española, Madrid, Gredos.

Lasarte, Pedro. (1989) ««No oyes ladrar los perros» de Juan Rulfo: peregrinaje hacia el origen», Inti. Revista de Literatura Hispánica, 1, núms. 29-30, 101-118.

LÁzaro Carreter, Fernando. (1980) «El problema del artículo en español», Estudios de lingüística, Barcelona, Crítica, 27-59.

Luraschi, Ilse Adriana. (1976) «Narradores en la obra de Juan Rulfo: estudio de sus funciones y efectos», Cuadernos hispanoamericanos, 308, febrero, 5-29.

Marino, Adrian. (1988) Comparatisme et théorie de la littérature, París, Presses Universitaires de France. 
Mauron, Charles. (1986) «Los orígenes de un mito personal en el escritor», en Eco, U., Goldmannn, L. y Bastide, R., Sociología contra psicoanálisis, Barcelona, Planeta Agostini, 105-127.

Montero, Rosa. (2001) El corazón del tártaro, Madrid, EspasaCalpe.

Montes Doncel, Rosa Eugenia. (2001) Del estilo a la estructura en la novela de Fernán Caballero, Sevilla, Diputación.

Montes Doncel, Rosa Eugenia. (2006) La tematología comparatista en la literatura y el cine (El aristócrata en su decadencia), Madrid, Pliegos.

Montes Doncel, Rosa Eugenia. (2008) Pragmática de la lírica y escritura femenina. Sor Juana Inés de la Cruz, Cáceres, Universidad de La Coruña/Universidad de Extremadura.

Montes Doncel, Rosa Eugenia, y Rebollo Ávalos, María José. (2006) «La intertextualidad (1967-2007). El largo periplo de un término teórico», Alfinge, 18, 157-180.

Naupert, Cristina. (2001) La tematología comparatista entre teoría y práctica, Madrid, Arco/Libros.

Olea Franco, Rafael. (2007) «Juan Rulfo, un maestro del cuento moderno", en Popovic Karic, P. y Chávez Pérez, F., Juan Rulfo: perspectivas críticas. Ensayos inéditos, México, Siglo XXI editores, 13-32.

Paredes, Juan. (2004) Para una teoría del relato. Las formas narrativas breves, Madrid, Biblioteca Nueva.

Paz Gago, José María. (2000) «Escritores de cine. Nuevo cine y narrativa en la novela latinoamericana», Anales de Literatura Hispanoamericana, 29, 43-74.

Perus, Françoise. (2012) ««No oyes ladrar los perros»: el oído y la mirada del narrador testigo», Juan Rulfo, el arte de narrar, México, Fondo de Cultura Económica, 125-144.

Pozuelo Yvancos, José María. (2010) Figuraciones del yo en la narrativa: Javier Marías y Enrique Vila-Matas, Universidad de Valladolid.

Quevedo, Francisco de. (1963) Obras completas. I. Poesía original, Barcelona, Planeta, edición de José Manuel Blecua. 
RAMA, Ángel. (1975) «Una primera lectura de «No oyes ladrar los perros»»", Revista de la Universidad de México, 29, 2, agosto, 1-8.

Remarque, Erich Maria. (1998) Im Westen nichts Neues, Colonia, Verlag Kiepenheuer \& Witsch. Traducción española: Sin novedad en el frente, Barcelona, Edhasa, traducción de J. Vilar, 2009.

Rulfo, Juan. ([1953] 1986a) El Llano en llamas, Madrid, Cátedra, edición de Carlos Blanco Aguinaga.

Rulfo, Juan. ([1955] 1986b) Pedro Páramo, Madrid, Cátedra, edición de José Carlos González Boixo.

Rulfo, Juan. ([1955] 2007) Pedro Páramo, Madrid, Cátedra, edición de José Carlos González Boixo (reimpresión, nueva edición desde 2002).

Rulfo, Juan. ([1955] 2017) El Llano en llamas, Madrid, Cátedra, edición de Françoise Perus.

Sender, Ramón J. (2018), Réquiem por un campesino español, Barcelona, Austral, edición de Antonio A. Gómez Yebra.

Tournier, Michel. (2007) Le Roi des Aulnes, París, Gallimard. Traducción española: El rey de los alisos, Los Premios Goncourt de novela, VIII, Barcelona, Plaza \& Janés, 1980, traducción de J. Ferrer Aleu, 113-501.

Trousson, Raymond. (1981) Thèmes et mythes. Questions de méthode, Universidad de Bruselas, 1981.

Verdugo, Waldemar. (2006) Magos de América: ensayo y entrevistas con Jorge Luis Borges, Gabriel García Márquez, María Luisa Bombal y Juan Rulfo, México, Edición Norte Sur y Librería Imagen.

Zweig, Stefan. (1994) Ungeduld des Herzens, Frankfurt am Main, Fischer Taschenbuch Verlag, Traducción española: La impaciencia del corazón, traducción de J. Fontcuberta, Barcelona, Acantilado, 2016. 